\title{
Successional trends and processes on a glacial foreland in Southern Iceland studied by repeated species counts
}

\author{
Taylor G. Glausen ${ }^{1}$ and Lawrence H. Tanner ${ }^{2^{*}}$ (D)
}

\begin{abstract}
Introduction: Primary succession on glacial forelands is increasingly relevant as rapid glacial retreat is exposing growing land areas to plant colonization. We investigated temporal trends, controls, and outcomes in floral succession on a subarctic glacial foreland. Specifically, we examined changes in community composition (mosses, low shrubs, forbs, trees, and graminoids) over long-term (decadal) and short-term ( $<10$ years) scales and attempted to identify the underlying processes responsible for the observed successional patterns.

Methods: The study area was the foreland of the Skaftafellsjökull, located in Vatnajökull National Park near the south coast of Iceland. We established nine transect lines at varying distances from the ice front representing surfaces of age ranging from less than one decade to over 100 years. Each transect consisted of five measurement stations of $1 \mathrm{~m}^{2}$ where we measured vegetative cover (VC), species richness (SR), and species density (SD) and calculated species evenness (SE). Measurements were made initially in 2007 and repeated at the same geographic coordinates in 2014.
\end{abstract}

Results: VC increased with distance from the ice front from 16\% to over $90 \%$. SR and SD increased from the youngest pioneer community through a mid-successional stage corresponding to an age of over 60 but less than 100 years. Increased VC but declining SR, SD, and SE characterized the oldest (over 100 years) bryophyte-dominated surfaces. Species turnover, which involved forbs almost exclusively, increased moderately from early through midsuccessional sites and declined on older sites. Comparison of the measurements made in 2014 to those made in 2007 demonstrates increased SR at mid-successional sites while SD remained relatively constant.

Conclusion: At a small scale, colonization is controlled by local factors such as microtopography and aspect, particularly in proximity to the glacier. At the landscape level, changes in VC and community structure are controlled by time and nutrient availability. Low nutrient levels and limited site availability favor bryophyte dominance on the oldest surfaces. The greatest community-level changes observed over the 7-year interval were increases in surface cover by mosses and low shrubs, particularly in mid-successional and older sites. These changes suggest that the community on the oldest surfaces has not yet reached equilibrium.

Keywords: Primary succession, Glacial foreland, Species richness, Species density, Bryophyte

\footnotetext{
* Correspondence: tannerLH@Lemoyne.edu

${ }^{2}$ Department of Biological and Environmental Sciences, Le Moyne College,

Syracuse, NY 13214, USA

Full list of author information is available at the end of the article
} 


\section{Introduction}

Forelands exposed by the retreat of glaciers following the conclusion of the Little Ice Age have long been considered optimal settings for the study of rates and processes of landscape modification through floral colonization and pedogenesis (see review in Matthews 1992). Of particular interest is the assessment of the relative importance and interplay of allogenic and autogenic processes in driving species succession as the landscape ages (Matthews and Whittaker 1987; Whittaker 1993). Most of the earlier studies of primary succession, from the late nineteenth and early twentieth centuries, were conducted on the forelands of temperate glaciers in alpine and Scandinavian Europe and North America where the surrounding plant communities are dominated by the boreal forest biome (Coaz 1887; Butters 1914; Cooper 1916, 1931; Lüdi 1921, 1958; Negri 1934, 1936; Fægri 1933; Friedel 1934, 1937, 1938). These glaciers continue to provide useful information for the interpretation of the controls of successional processes on their forelands (Jones and Moral 2005). Particularly well-known are the classic studies that examined the record of 200 years of succession on the glacial foreland in Glacier Bay, Alaska (Crocker and Major 1955; Chapin et al. 1994; Fastie 1995). Of necessity, due mainly to limits of accessibility, few studies have focused on the ecological changes that occur following deglaciation in arctic or subarctic settings, with the major exceptions being those conducted on the forelands of glaciers on Svalbard, which are particularly well studied (Liestøl 1988; Dowdeswell 1995; Liengen and Olsen 1997; Lefauconnier et al. 1999; Liengen 1999; Hodkinson et al. 2003). Notably, Jones and Henry (2003) concluded that the differences in successional processes between temperate and high arctic glacial systems are mainly differences in the species involved and the rates of change, which are faster in temperate environments, not the processes themselves.

The land surfaces exposed in front of many retreating glaciers, whether temperate or high latitude, constitute forelands with a maximum age corresponding to the local maximum advance during the Little Ice Age, and commonly an associated distal outwash plain. The ages of different surfaces within such sequences may be constrained by recessional moraines of known or estimated ages, and therefore these surfaces constitute chronosequences on which rates of various ecological processes can be measured (Vreeken 1975). Nonetheless, measuring primary succession on chronosequences has required a certain level of creativity. The review by Matthews (1992) suggested that one of the most successful approaches is the establishment of permanent plots that can be revisited at multi-year intervals, and the changes recorded. This approach was employed with great success at Glacier Bay, for example (Cooper 1923, 1931, 1939). However, this method may not be practical in some instances, such as in public areas, e.g., national parks.

Recognizing that anthropogenic climate change disproportionately affects higher latitudes (IPCC 2014) has led to renewed interest in landscape-scale ecological and pedogenic processes in arctic and subarctic landscapes, with particular attention to the effects of climate change (Starfield and Chapin 1996; Jägerbrand et al. 2012). Modern climate change has created exceptional opportunities to examine ecological processes and rates of landscape modification in Iceland. Warming is causing the recession of nearly all outlet glaciers of the large Icelandic ice caps, with retreats of well over $1 \mathrm{~km}$ documented for many of these glaciers in the last century (Sigurðsson 2005). This recession has exposed fresh surfaces of glacial ice-contact and outwash deposits to floral colonization and soil formation, resulting in the formation of chronosequences with maximum durations of 100 years or more. The study described herein examines the changes in the floral community across the chronosequence of a retreating glacier in southern Iceland with the dual objectives of (1) studying trends in changing floral cover and community structure at various successional stages and attempting to identify the underlying causes, and (2) testing rates of change through comparison of measurements made 7 years apart at the same locations. As a corollary, the study tests the use of Global Positioning System (GPS) data to record the locations of long-term study sites, rather than relying on photographs or maintaining established plots.

\section{Methods}

\section{Location and setting}

Vatnajökull, the largest ice cap in Iceland (and Europe), measures $7800 \mathrm{~km}^{2}$ (Baldursson et al. 2018) and is the source of nearly 30 individual outlet glaciers, most of which occupy valleys or broad, subglacial channels (Fig. 1). For the most part, these glaciers reached their Little Ice Age maximum extent near the end of the nineteenth century and have been in a recession much of the time since. Most of these glaciers were in retreat through the 1930s and into the 1940s, responding to a warming climate, but following cooling early in the latter half of the twentieth century, recession rates slowed through the 1950s and 1960s, and some glaciers re-advanced in the late 1960s through 1970s. Consistent warming since the mid-1980s has led to retreat of almost all of these outlet glaciers over the last two decades. Data on the movements of these glaciers have been and continue to be collected by a combination of scientists and local residents. Tabulations of these data are published regularly in the journal Jökull. This 


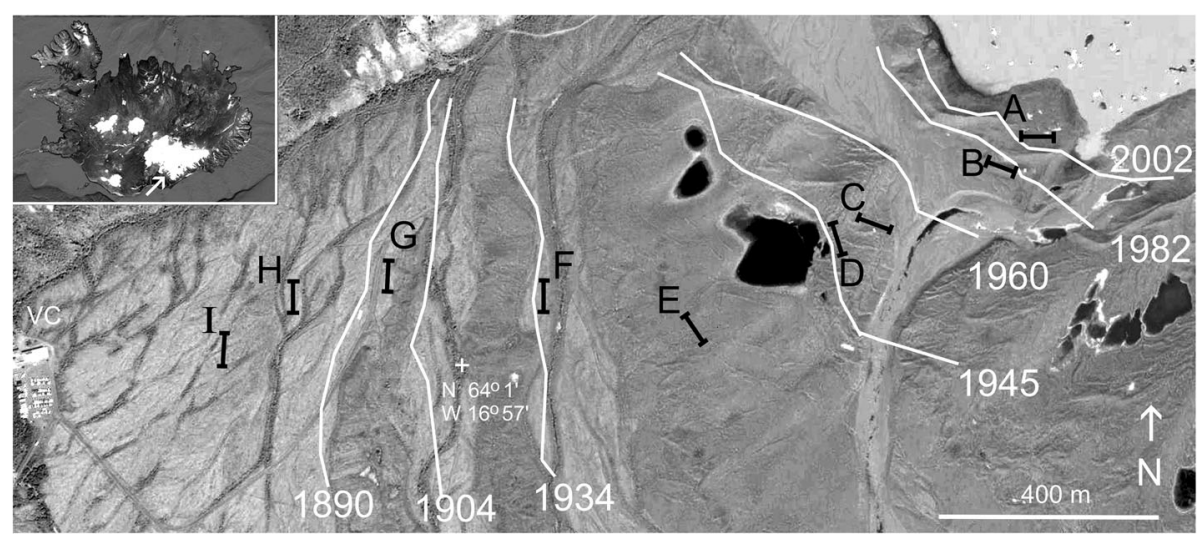

Fig. 1 Map of the sampling sites on the Skaftafellsjökull foreland for 2007 and 2014 with estimated positions of the ice front (see text). Black line segments mark the sample transect locations. Darker areas on the foreland are moraines; lighter areas are terraces of abandoned melt-water streams and bars on the distal outwash plain. These are incised by narrow channels that are darker due to the higher proportion of shrubs and low trees. Inset shows the location of Skaftafellsjökull outlet glacier on southern margin of the Vatnajökull. VC= park visitor center. Figure adapted from imagery downloaded from Google Earth ${ }^{\circledast}$ (image acquisition date August 10, 2015)

database is maintained by the Hydrologic Service of the National Energy Authority (located in Reykjavik).

The retreat of these glaciers over the past century or more has exposed foreland areas with varying topography. Most of the non-surging glaciers have left recessional moraines that can be dated reasonably accurately. For example, at Skaftafell, in Vatnajökull National Park (formerly Skaftafell National Park), the most distal moraine of the Skaftafellsjökull that is clearly identifiable is dated to the position of the ice front from 1890 to 1904. A much more pronounced topography is formed by a set of nested moraines that date from the position of the glacial front in 1945 (Fig. 1). The more proximal moraines date to the positions of the glacial front in 1954, 1960, 1982, and 2002 (Perrson 1964; Sigurðsson 2005; Hannesdóttir et al. 2014). Between the moraines are flatter areas formed by alluvial outwash terraces and incised channels. The ages of these inter-moraine surfaces generally are not as well constrained, other than by the moraines that form their boundaries, due to the likelihood of continued reactivation of the outwash channels over the course of many years. Consequently, the surfaces at Skaftafell can best be characterized as pre-1890, 18901904, 1904-1945, 1945-1960, 1960-1982, 1982-2002, and post-2002. Nonetheless, the foreland of the Skaftafellsjökull forms a chronosequence, more specifically a post-incisive chronosequence (Vreeken 1975; Huggett 1998) in which distance from the ice front equates (very approximately) to the time of exposure of the surface. The topography of other glacial forelands of the non-surging Vatnajökull outlet glaciers is similar, with prominent moraines formed approximately contemporaneously as those at Skaftafell.

The study site is located at latitude $\mathrm{N} 64^{\circ} 1.0^{\prime}$ and has a mean elevation of ca. $100 \mathrm{~m}$ asl. The southeastern coast of Iceland is subject to a cool maritime climate. Mean annual precipitation on this area of the south coast is approximately $1800 \mathrm{~mm}$ (Vilmundardóttir et al. 2014). The annual mean temperature is $4{ }^{\circ} \mathrm{C}$ to $6^{\circ} \mathrm{C}$, with a winter (January) mean of near $0{ }^{\circ} \mathrm{C}$, and a summer (July) mean of $10^{\circ} \mathrm{C}$, although air temperatures in the proximity of the glacier are greatly variable and often significantly cooler. In proximity to the Skaftafellsjökull ice front, the air temperature close to ground level (at 5 $\mathrm{cm}$ ) has been found to decrease by as much as $9^{\circ} \mathrm{C} \mathrm{com}$ pared to distal locations (Lindröth 1965). The land surface closest to the glacier is also subject to glacial winds of variable strength. Such winds are a common phenomenon formed by the high-temperature gradient immediately above the glacial ice (Hoinker 1954; Geiger 1971). No data specific to the Skaftafellsjökull are available, but the wind has been studied on the outwash plain of the nearby Skeiðarárjökull (Wójcik 1973), where the strength and the effective distance of the wind varies diurnally with solar heating and nightly cooling of the land surface in front of the glacier. Prior to 1967, the study area was farmland (for sheep farming). This area was largely abandoned for grazing after the national park was established in 1967, and formally fenced off in 1987 (Vilmundardóttir et al. 2015a).

\section{Previous work}

A survey of species richness at various distances from the glacial ice front was conducted over 50 years ago (Perrson 1964), although the utility of the results is compromised by the locations of the sampling sites. The author intentionally avoided sampling in the topographic low areas (e.g., abandoned melt-water stream channels) and admitted that many of the sample locations were subjected to a microclimate bias from the shelter 
afforded by proximity to the rock cliff that borders the glacial foreland (and the glacier) to the west. More recent studies have compared soil composition (carbon and nitrogen content) and vegetative cover at different distances from the ice front (Tanner et al. 2013; Vilmundardóttir et al. 2015a) and the ecology of the soil organisms and their relationship to primary successional processes (van Leeuwen et al. 2018).

\section{Techniques}

Nine sites for measurement were selected from a larger set of sites on the Skaftafellsjökull foreland where soil properties were studied previously (Tanner et al. 2013). The sites were chosen to represent locations at varying distances from the ice front, as a proxy for age, and to examine differences in local topography (e.g., five sites on moraines, one site in a channel swale, and three sites on the outwash plain). Site A is the most proximal to the ice front, located on the glacial-facing slope (equals proximal aspect) of the most recent moraine, which is dated to the position of the ice front in 2002 (Hannesdóttir et al. 2014). Site B, located ca. $70 \mathrm{~m}$ southwest of site $\mathrm{A}$, is on a flat at the top of the next most proximal moraine from the ice front, associated with the ice position in 1982. Site C is located on the northeast-facing slope (proximal aspect) of a moraine ridge that marks the position of the ice front ca. 1954 (Perrson 1964). Site $\mathrm{D}$ is situated in a slight hollow on the southwest-facing slope (away from the glacier or distal aspect) of the moraine ridge from 1954, overlooking a kettle pond in the 1945 moraine. Site $\mathrm{E}$ is on a broad flat at the top of the 1945 moraine; the date of deglaciation of the site is estimated at 1938 (based on data from Sigurðsson 2005). Site $\mathrm{F}$ is located on the terrace of a stream channel in a swale immediately east (toward the glacier) of the moraine associated with the ice position in 1934 (Sigurðsson 2005). However, this swale was occupied by an outwash channel active as recently as 1960 (Perrson 1964). Site $G$ is situated adjacent to the margin of the oldest boulder moraine, associated with the position of the ice margin between 1904 and 1890. Sites H and I are located on the outwash plain distal (west) of the 1890 ice front. The topography here is not entirely flat but consists instead of very subdued ridges and swales that are relicts of the period when the outwash channels on the plain were occupied. The site I is ca. $140 \mathrm{~m}$ south-southwest of site $\mathrm{H}$ in a more distal position on the outwash plain (Fig. 1).

At each site, a transect line was established parallel to the ice front with five measurement stations set $10 \mathrm{~m}$ apart. Starting points for stations were chosen without bias for substrate, i.e., individual stations may have included non-vegetated boulders. At each station, measurements were made using a $0.5 \mathrm{~m} \times 0.5 \mathrm{~m}$ quadrat that was rotated spatially to provide $1.0 \mathrm{~m}^{2}$ of continuous coverage per station. Within the quadrat, all individual vascular plant species were identified using Kristinsson (2013) as a reference and the percentage of ground area covered by vascular plant species and bryophytes estimated, with each estimate rounded up to the nearest whole percent for the quadrat. Lichens (crustose or other) and biological soil crusts were not included in the species counts. The initial measurements were conducted in early June of 2007; the second set of measurements was conducted in 2014, also in early June, at the coordinates recorded for the sites in 2007. However, it is noted that the accuracy of the GPS instruments used (in 2007 and 2014) allows for meter-scale variation in site location.

Over 50 vascular plants were identified to the species level on the foreland of the Skaftafellsj kull (Table 1). Mosses were not identified to the species level, but substantial portions of the foreland community are dominated by Racomitrium spp., particularly Racomitrium canescens (hoary fringe moss; Perrson 1964). Similarly, graminoids, other than Festuca rubra (red fescue) and Poa alpina (alpine meadow grass) were not identified to the species level. The majority of species, particularly among forbs, have very low frequencies of occurrence, typically accounting for less than $1 \%$ of cover (but rounded to $1 \%$ for all calculations). Commonly, quadrats included one or more specimens with insufficient blossom or leaf characteristics for identification. These individuals therefore are not included in species counts, but their presence is included in estimates of vegetation coverage.

Community structure is represented by assigning all species to the following groups. All bryophytes are grouped as mosses, although as noted above $R$. canescens is dominant. All non-graminoid herbaceous species are designated as forbs. Empetrum nigrum (crowberry) is generally the most abundant member of the group designated low shrubs, but other common representatives of the group are Arctostaphylos uva-ursi (bearberry), saxifrages, primarily Saxifraga oppositifolia (purple saxifrage), Thymus praecox (wild thyme), and Calluna vulgaris (Scotch heather). The willows and birches have thicker, woodier stems than the other shrubs and therefore are treated as separate groups. The willows consist of the species Salix lanata (wooly willow), S. herbacea (dwarf willow), and S. phylicifolia (tea-leaved willow). Graminoids includes all grasses, fescues, and rushes, of which $F$. rubra and $P$. alpina are the most common. The tree species Betula nana (dwarf birch) and B. pubescens (downy birch) constitute the final group.

\section{Statistical analyses}

For both data series (2007 and 2014), the individual results for each of the four quadrants at each station were 
Table 1 List of species identified at Skaftafell in this study (Kristinsson 2013)

\begin{tabular}{|c|c|}
\hline Species name & Common name \\
\hline Alchemilla alpina & Alpine lady's mantle \\
\hline Arabidopsis petraea & Northern rock cress \\
\hline Arctostaphylos uva-ursi & Bearberry \\
\hline Arenaria norvegica & Arctic sandwort \\
\hline Armeria maritima & Thrift \\
\hline Bartsia alpina & Alpine bartsia \\
\hline Betula nana & Dwarf birch \\
\hline B. pubescens & Downy birch \\
\hline Bistorta vivipara & Alpine bistort \\
\hline Botrychium lunaria & Common moonwort \\
\hline Calluna vulgaris & Scotch heather \\
\hline Cerastium alpinum & Alpine mouse ear \\
\hline C. fontanum & Common mouse ear \\
\hline Draba norvegica & Rock whitlow grass \\
\hline Dryas octopetala & Mountain avens \\
\hline Empetrum nigrum & Crowberry \\
\hline Epilobium anagallidifolium & Alpine willowherb \\
\hline Equisetum arvense & Field horsetail \\
\hline E. pratense & Meadow horsetail \\
\hline Erigeron borealis & Alpine fleabane \\
\hline Festuca rubra & Red fescue \\
\hline F. richardsonii & Arctic fescue \\
\hline Galium verum & Lady's bedstraw \\
\hline G. normanii & Slender bedstraw \\
\hline Juniperus communis & Common juniper \\
\hline Myosotis arvensis & Field forget-me-not \\
\hline Omalotheca supina & Alpine arctic cudweed \\
\hline Poa alpina & Alpine meadow grass \\
\hline Minuartia rubella & Mountain sandwort \\
\hline Racomitrium canescens (etc.) & Hoary fringe moss (and other mosses) \\
\hline Rhodiola rosea & Roseroot \\
\hline Pinguicula vulgaris & Common butterwort \\
\hline Potentilla crantzii & Alpine cinquefoil \\
\hline Sagina saginoides & Alpine pearlwort \\
\hline Salix arctica & Arctic willow \\
\hline S. phylicifolia & Tea-leaved willow \\
\hline S. herbacea & Dwarf willow \\
\hline S. lanata & Wooly willow \\
\hline Saxifraga oppositifolia & Purple saxifrage \\
\hline S. cespitosa & Tufted saxifrage \\
\hline Sedum villosium & Hairy stonecrop \\
\hline S. acre & Common stonecrop \\
\hline Selaginella selaginoides & Lesser clubmoss \\
\hline
\end{tabular}

Table 1 List of species identified at Skaftafell in this study (Kristinsson 2013) (Continued)

\begin{tabular}{ll}
\hline Species name & Common name \\
\hline Silene acaulis & Moss campion \\
S. uniflora & Sea campion \\
Thymus praecox & Wild thyme \\
Tofieldia pusilla & Scottish asphodel \\
Trifolium repens & White clover \\
Vaccinium uliginosum & Bog bilberry \\
Veronica alpina & Alpine speedwell \\
V. fruticans & Rock speedwell \\
\hline
\end{tabular}

averaged. Thus, for each site, the five stations provide a measure of the species richness (SR), the total number of species present on a surface of consistent age, as well as the local (station to station) variability of the community structure, represented by the standard error of the major elements of the community (e.g., mosses and low shrubs). The species density (SD), the number of species per square meter, was calculated as the mean of the five stations for each site. Additionally, species evenness (SE) was calculated from

$$
\mathrm{SE}=H / \ln S R
$$

where $H$ is Shannon's diversity index

$$
H=-\sum P_{i} \ln P_{i}
$$

where $P_{i}$ is the proportion of the population constituted by each species (Hill 1973). Absolute species turnover $\left(\beta_{A}\right)$ as a function of time (from 2007 to 2014) was calculated for each site by adapting the formula commonly used for a turnover as a function of the spatial distribution

$$
\beta_{A}=\left(S_{2007}-c\right)+\left(S_{2014}-c\right)
$$

where $S_{2007}$ and $S_{2014}$ are the total numbers of species recorded in 2007 and 2014, respectively, and $c$ is the number of species common to both sets of measurements (Albert and Reis 2011).

The significance of the changes in the community at each site from 2007 to 2014 was tested by independent $t$ test of the site data from both series, e.g., site A 2007 data were compared to site A 2014 data. These $t$ test comparisons (2007 vs. 2014) examined changes of total vegetation cover, cover by mosses, and cover by low shrubs with results of significance reported for $p<0.05$.

\section{Results}

The compiled data summaries for total vegetative cover (VC) and cover by each of the groups described above for individual sites as measured in 2007 and 2014 are 
presented in Table 2 and shown in Fig. 2. Comparisons of the two major vegetation groups (mosses and low shrubs) for each site in 2007 and 2014 are presented in Fig. 3a. Calculations of SR, SD, SE, and $\beta_{A}$ for each site for both 2007 and 2014 are presented in Table 3, along with independent $t$ test comparisons of the 2007 vs. 2014 pairs for each site. Site-by-site comparisons of SR and SD for 2007 and 2014 are shown in Fig. 3b.

\section{Chronosequence trends}

The 2007 and 2014 datasets both demonstrate an overall increase in VC from the sites most proximal to the glacier toward those sites more distal (Fig. 2). The data series for 2007 demonstrates large increases in VC in the early stages of succession, with a major increase between sites A (2002) and B (1982), the former representing a very young surface and the latter corresponding to 35 years of colonization (in 2007). The increase in VC from site A to site B records mainly the increase of mosses, but a substantial increase in forbs also occurred and willows first appeared at this site. SR is near peak value at this site, primarily due to the appearance of seven new species of forbs. Among the low shrubs, $E$. nigrum first appears here. A major increase in $\mathrm{VC}$ also occurs between sites C (1954) and D (1945). Although the sites are very close spatially and temporally, they represent very different aspects of the topography. Site C lies on a northeast slope facing the glacier (proximal aspect) and therefore receives less direct sunlight and is exposed directly to glacial winds; $\mathrm{VC}$ and moss have almost the same percentage of coverage as at the much younger site B. Site D, which is on the sheltered southwest-facing slope (distal aspect) demonstrated a substantial increase in $\mathrm{VC}$, primarily through an increase in low shrubs and willows (Fig. 3a). Both SR and SD increased considerably from site C to site D (Fig. 3b). Site E (1938), which is located on a horizontal surface at the top of a moraine (and less sheltered), had lower VC than site D despite the greater age of the land surface; moss coverage remained nearly constant, while forbs increased and the coverage by low shrubs and willows decreased. SR and SD were unchanged from site D to site E. Site F (1960) experienced less exposure time than did site E (1938) but is situated in a more sheltered location. VC was almost the same as at site $\mathrm{E}$, but forbs were much less common and cover by both moss and low shrubs was slightly higher. SR and SD were lower than at site E. The surface at site G (1890-1904), on the margin of the oldest moraine, is approximately 60 years older than site $\mathrm{F}$, but $\mathrm{VC}$ and moss coverage were similar to site $\mathrm{F}$, whereas species richness and density both increased. The oldest sites, G, H, and I (the latter two are pre-1904), demonstrated progressive increases in both $\mathrm{VC}$ and moss coverage (Fig. 3a), accompanied by progressive decreases in both SR and SD (Fig. 3b).

Overall, the data series for 2014 demonstrates a trend that is broadly similar to that observed in 2007 of increasing $\mathrm{VC}$ and moss across the chronosequence,

Table 2 Total vegetative cover (VC), \% cover by vegetation groups and site characteristics, 2007 compared to 2014 (with standard error for major groups). See text for explanation of the estimated site age

\begin{tabular}{|c|c|c|c|c|c|c|c|c|c|c|}
\hline Class & $\begin{array}{l}\text { Sample } \\
\text { year }\end{array}$ & $\begin{array}{l}\text { Site A } \\
(2002)\end{array}$ & $\begin{array}{l}\text { Site B } \\
(1982)\end{array}$ & $\begin{array}{l}\text { Site C } \\
(1954)\end{array}$ & $\begin{array}{l}\text { Site D } \\
(1945)\end{array}$ & $\begin{array}{l}\text { Site E } \\
(1938)\end{array}$ & Site F (1960) & $\begin{array}{l}\text { Site G (1890- } \\
1904)\end{array}$ & $\begin{array}{l}\text { Site H (pre- } \\
1890)\end{array}$ & $\begin{array}{l}\text { Site I (pre- } \\
\text { 1890) }\end{array}$ \\
\hline \multirow[t]{2}{*}{ VC } & 2007 & $16.0 \pm 4.9$ & $49.1 \pm 5.9$ & $47.4 \pm 8.4$ & $79.1 \pm 8.1$ & $63.8 \pm 4.5$ & $67.9 \pm 8.5$ & $66.2 \pm 11.2$ & $75.2 \pm 12.1$ & $86.1 \pm 9.6$ \\
\hline & 2014 & $13.6 \pm 2.9$ & $31.2 \pm 3.7$ & $45.2 \pm 15.7$ & $100 \pm 5.6$ & $57.7 \pm 11.7$ & $100 \pm 8.2$ & $93.8 \pm 2.9$ & $92.5 \pm 6.9$ & $92.7 \pm 11.5$ \\
\hline \multirow[t]{2}{*}{ Moss } & 2007 & $10.5 \pm 5.2$ & $32.7 \pm 5.2$ & $35.1 \pm 8.5$ & $36.9 \pm 3.0$ & $35.4 \pm 8.1$ & $48.8 \pm 7.4$ & $49.9 \pm 13.6$ & $54.7 \pm 12.5$ & $76.0 \pm 8.8$ \\
\hline & 2014 & $7.6 \pm 3.4$ & $15.2 \pm 3.6$ & $20.4 \pm 8.5$ & $69.0 \pm 8.2$ & $37.2 \pm 13.4$ & $60.4 \pm 8.8$ & $77.6 \pm 6.3$ & $62.8 \pm 16.7$ & $79.4 \pm 9.2$ \\
\hline \multirow{2}{*}{$\begin{array}{l}\text { Low } \\
\text { shrubs }\end{array}$} & 2007 & $0.6 \pm 0.4$ & $1.6 \pm 0.9$ & $4.9 \pm 1.8$ & $24.8 \pm 4.6$ & $6.9 \pm 1.4$ & $13.1 \pm 5.2$ & $9.0 \pm 5.2$ & $9.1 \pm 4.4$ & $5.6 \pm 2.9$ \\
\hline & 2014 & $1.4 \pm 0.4$ & $4.1 \pm 0.8$ & $13.8 \pm 5.1$ & $27.3 \pm 7.1$ & $8.2 \pm 2.2$ & $29.0 \pm 6.1$ & $14.6 \pm 5.3$ & $25.1 \pm 10.3$ & $11.7 \pm 6.7$ \\
\hline \multirow[t]{2}{*}{ Graminoids } & 2007 & 3.9 & 2.1 & 2.6 & 2.2 & 2.6 & 1.4 & 3.2 & 1.7 & 0.4 \\
\hline & 2014 & 3.8 & 3.1 & 1.7 & 4.3 & 1.5 & 1.2 & 0.8 & 0.8 & 1.0 \\
\hline \multirow[t]{2}{*}{ Forbs } & 2007 & 1.0 & 10.0 & 4.1 & 5.7 & 12.0 & 1.1 & 2.8 & 2.1 & 0.6 \\
\hline & 2014 & 0.8 & 5.2 & 4.6 & 4.5 & 10.8 & 3.7 & 0.4 & 2.0 & 0.4 \\
\hline \multirow[t]{2}{*}{ Willow } & 2007 & 0 & 2.4 & 0.8 & 9.5 & 3.4 & 2.5 & 0.6 & 0.5 & 1.7 \\
\hline & 2014 & 0 & 4.6 & 1.7 & 9.7 & 0.3 & 7.4 & 0.4 & 1.1 & 0 \\
\hline \multirow[t]{2}{*}{ Birch } & 2007 & 0 & 0.2 & 0 & 0 & 3.8 & 0 & 0.8 & 7.1 & 1.6 \\
\hline & 2014 & 0 & 0 & 4.4 & 0 & 0 & 5.6 & 0.2 & 1.4 & 0.3 \\
\hline Soil N (\%) & 2007 & 0.03 & 0.03 & 0.16 & 0.17 & 0.09 & 0.18 & 0.17 & 0.12 & 0.14 \\
\hline $\begin{array}{l}\text { Surface } \\
\text { type }\end{array}$ & & Moraine & Moraine & Moraine & Moraine & Moraine & $\begin{array}{l}\text { Channel } \\
\text { swale }\end{array}$ & Moraine margin & $\begin{array}{l}\text { Outwash } \\
\text { plain }\end{array}$ & $\begin{array}{l}\text { Outwash } \\
\text { plain }\end{array}$ \\
\hline
\end{tabular}




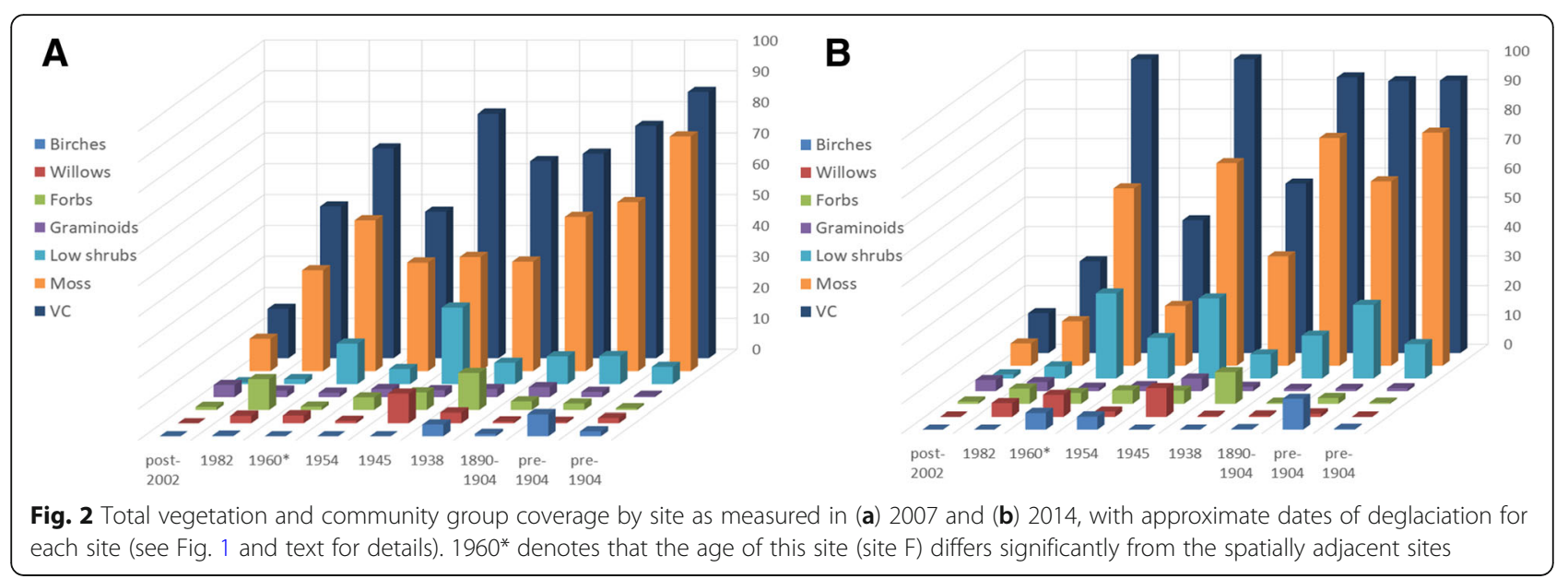

particularly among sites A through D (2002 to 1945). As recorded by the earlier series, site $\mathrm{D}$ exhibited a pronounced peak in $\mathrm{VC}$ and low shrub cover, although the 2014 set demonstrated a much larger increase in moss cover than seen in 2007. In both data series, site E (1938) has lower VC than site D reflecting a drop in the cover by low shrubs, accompanied by a decrease in moss cover in the 2014 measurement. Unlike the 2007 series, the 2014 series reached peak VC at site F (1960) and maintained consistently high $\mathrm{VC}$ and moss and shrub cover through site I (pre-1904; Fig. 3a). SR and SD trends also are similar in both data series, with SR and $\mathrm{SD}$ reaching peaks at site $\mathrm{E}$ and declining through the remaining sites (Fig. 3b).

\section{Discussion}

\section{Changes in community structure}

Studies of temperate and Arctic glacier forelands have led to the broad conclusion that succession is a complex process that is difficult to characterize, particularly in the pioneering stage, due to highly variable microsite factors, such as grain size of the substrate and moisture availability, but regardless, it proceeds generally to reach a uniform climax community (Jones and Henry 2003; Burga et al. 2010). This may be the case on the Skaftafellsjökull foreland where succession proceeded from a mixed low shrub-moss heath with abundant forbs in earlier stages to an increasingly moss-dominated heath in later stages (Figs. 2 and 3a). Similar observations were made by Vilmundardóttir et al. (2015b) on the foreland of the Breiðamerkurjökull, another outlet glacier of the Vatnajökull ca. $35 \mathrm{~km}$ to the east. At Skaftafell, SR, SD, and species turnover $\left(\beta_{A}\right)$ increased in the earlier stages and peaked at middle stages, but declined in later stages, as did the coverage by the low shrub assemblage and forbs (Figs. 3a and b). The early stage increases in SR and SD are commonly attributed to facilitation, such as substrate stabilization by the early colonizers (Eichel 2019). The late-stage decline of shrubs and forbs coincided with the increasing domination of the community

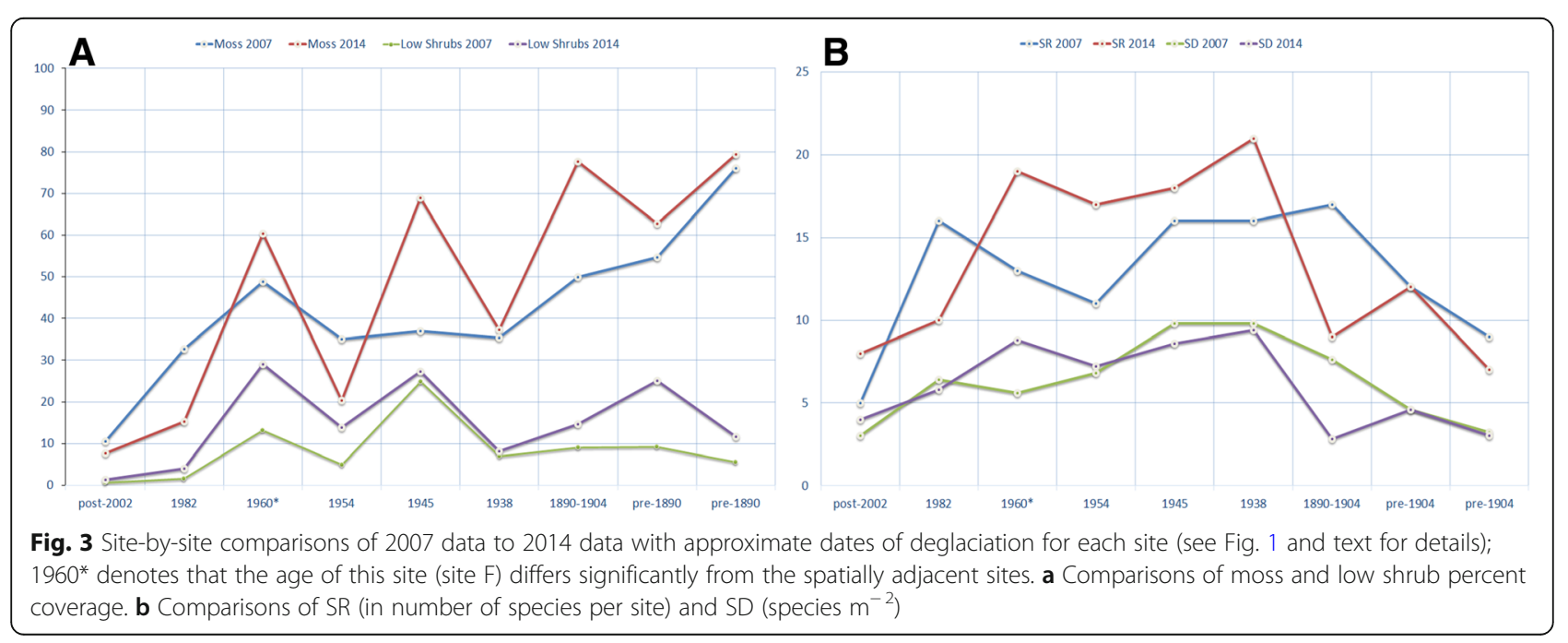


Table 3 Statistical analyses of species data

\begin{tabular}{|c|c|c|c|c|c|c|c|c|c|c|}
\hline Items & $\begin{array}{l}\text { Sample } \\
\text { year }\end{array}$ & $\begin{array}{l}\text { Site A } \\
(2002)\end{array}$ & $\begin{array}{l}\text { Site B } \\
(1982)\end{array}$ & $\begin{array}{l}\text { Site C } \\
\text { (1954) }\end{array}$ & $\begin{array}{l}\text { Site D } \\
\text { (1945) }\end{array}$ & $\begin{array}{l}\text { Site E } \\
\text { (1938) }\end{array}$ & $\begin{array}{l}\text { Site F } \\
(1960)\end{array}$ & $\begin{array}{l}\text { Site G (1890- } \\
1904)\end{array}$ & $\begin{array}{l}\text { Site H (pre- } \\
\text { 1890) }\end{array}$ & $\begin{array}{l}\text { Site I (pre- } \\
\text { 1890) }\end{array}$ \\
\hline \multirow[t]{2}{*}{ SR } & 2007 & 5 & 13 & 11 & 16 & 16 & 16 & 17 & 12 & 9 \\
\hline & 2014 & 8 & 19 & 17 & 18 & 10 & 21 & 9 & 12 & 7 \\
\hline \multirow[t]{2}{*}{ SD } & 2007 & 3 & 5.6 & 6.8 & 9.8 & 6.4 & 9.8 & 7.6 & 4.6 & 3.2 \\
\hline & 2014 & 4 & 8.8 & 7.2 & 8.6 & 5.8 & 9.4 & 2.8 & 4.6 & 3.0 \\
\hline \multirow[t]{2}{*}{ SE } & 2007 & 0.65 & 0.42 & 0.43 & 0.60 & 0.43 & 0.63 & 0.36 & 0.40 & 0.22 \\
\hline & 2014 & 0.56 & 0.51 & 0.59 & 0.45 & 0.68 & 0.47 & 0.33 & 0.48 & 0.28 \\
\hline$\beta_{A}$ & $2007 / 2014$ & 7 & 11 & 11 & 12 & 12 & 12 & 10 & 7 & 6 \\
\hline$t$ test & $2007 / 2014$ & & & & & & & & & \\
\hline VC & & ns & 0.03 & ns & ns & ns & 0.026 & 0.04 & ns & ns \\
\hline Moss & & ns & 0.024 & ns & 0.006 & ns & ns & ns & ns & ns \\
\hline $\begin{array}{l}\text { Low } \\
\text { shrubs }\end{array}$ & & ns & ns & ns & ns & ns & ns & ns & ns & $\mathrm{ns}$ \\
\hline
\end{tabular}

$S R$ species richness (vascular plants), $S D$ species density (species $/ \mathrm{m}^{2}$ ), SE species evenness, $V C$ vegetative cover, $\beta_{A}=$ absolute species turnover, ns (not significant) indicates $p>0.05$

by mosses, recorded also by decreasing SE (Fig. 3a). The earlier study of the Skaftafellsjökull foreland by Perrson (1964) yielded similar results, although the maximum values for SR and SD reported in that study were higher than we observed. We note, however, that the sampling sites of that study were concentrated mainly within 100 $\mathrm{m}$ of the base of the ridge (Skaftafellsheiði) that borders the foreland to the northwest (Fig. 1). The presence of this ridge provides substantial shelter to the northwestern margin of the foreland, which is a birch woodland that may have acted in part as a refugium during the Little Ice Age glacial advance (Lindröth 1965). Nevertheless, the pattern reported herein of SR increasing through the middle stages on the chronosequence and decreasing on the older landscape matches the earlier report (Perrson 1964).

Some studies of glacial forelands have suggested that the early to middle stage peak in SR and SD may reflect the abundance of sites available for colonization, as well as the overlap of species from pioneering and intermediate stages (Jones and Henry 2003). The mid-stage peak and late-stage decline in diversity recorded here by SR, $\mathrm{SD}$, and SE is a trend that has been cited in many studies across successional environments ranging from the Arctic to the tropics (Perrson 1964; Matthews 1992; Zollitsch 1969; Elven and Ryvarden 1975; Connell and Slatyer 1977). Jones and Moral (2005) noted, however, that these results can depend on whether the scale of observation is very local or at the landscape level. Some of these studies have suggested that species competition increases in later stages of succession only when VC approaches near maximum coverage of the foreland (Elven and Ryvarden 1975; Connell and Slatyer 1977; Jones and Henry 2003). Kjær et al. (2018) concluded specifically that species competition in later stages reflects the relative decrease in abiotic stress that dominates the early successional processes in proglacial environments. The observations presented herein are consistent with the conclusion that competition between bryophytes and vascular species (i.e., forbs and low shrubs) increased as $\mathrm{VC}$ increased on surfaces that are both older and at a greater distance from the ice front.

\section{Short-term trends}

Precise comparison of data from 2007 to 2014 is somewhat problematic due to the level of small-scale (meter-scale) variation of $\mathrm{VC}$ at individual sites, demonstrated by the high standard error associated with many of the measurements, compounded by the meter-scale imprecision of the GPS coordinates. Hence, the few statistically significant differences in the measures at individual sites from 2007 compared to 2014 cannot be attributed unambiguously to successional changes across the 7-year measurement interval. In particular, we note that the measurements at site $\mathrm{B}$ recorded a statistically significant decrease in both VC and moss from 2007 to 2014, contrary to the trend of nearly constant (within the range of error) or increasing coverage between the measurements. Otherwise, differences between the two data series are notably consistent and suggest a temporal trend observable at short time scales. Moreover, these results indicate that reliance on GPS coordinates to establish repeated sampling sites, although not ideal and subject to large standard error, is a useful proxy for more permanent site markers.

At sites D (1945) through I (pre-1904), almost all measures indicate higher levels of $\mathrm{VC}$, moss cover, and cover by low shrubs in 2014 than in 2007 (Fig. 3a), with concomitant lower levels of forbs and graminoids. Some of the differences involve species observed at more 
proximal sites in 2014 than in 2007. For example, in 2007, the most proximal site where Epilobium anagallidifolium (alpine willowherb) was observed was site B (1982), but in 2014, it was found at site A (2002). Similarly, the most proximal location of A. uva-ursi in 2007 was site D (1945), while in 2014, it was recorded at site C (1954). Although not all differences are statistically significant, the consistency of the changes from 2007 to 2014 indicates that the 7-year measurement interval was sufficient to allow measurable successional changes in $\mathrm{VC}, \mathrm{SR}$, and community structure.

Notably, at the oldest pre-1890 sites (H and I), the proportion of mosses increased only slightly from 2007 to 2014 whereas low shrub coverage more than doubled. These changes suggest that community structure has not yet reached an equilibrium state on the oldest surfaces. The most distal portion of the Skaftafellsj kull foreland is the outwash plain formed following the Little Ice Age maximum advance, approximately 120 to 130 years ago, but even so, successional processes may not have had sufficient time to achieve a climax community; this may take the form of a mixed low shrub-moss heath that ultimately may be invaded by the birch woodland encroaching from the base of the Skaftafellsheiði ridge to the northwest. The time frame required for successional landscape maturity varies widely and depends very much on local factors (Matthews 1992). On the Storbreen Glacier foreland (southern Norway), for example, measurable successional changes were still occurring on the oldest portions of after 220 years (Matthews 1978).

\section{Importance of aspect}

Sites A (2002) and C (1954) are on slopes facing the glacier (proximal aspect) and therefore exposed to the glacial winds, whereas site B (1982) is neutral and site D (1945) faces away from the glacial front (distal aspect) and therefore is sheltered. We suggest that eolian processes associated with the glacial winds provide an inhibitory effect on plant colonization. Periodically these winds may exert an erosive force that may hinder bryophyte colonization due to their lack of anchoring root systems. Additionally, colonization by rooted vascular plants could be reduced if the winds remove or prevent the accumulation of silt-sized substrate between larger gravel and boulders that would otherwise facilitate root penetration and water retention. This role of aspect should decrease with distance, as the strength of the glacial wind decreases with distance from the glacier. This supposition is supported by the relatively small differences in VC between site F (1960), which is much more distal than site $\mathrm{C}$, but is sheltered by its location in a swale between morainal ridges, and the nearby site $\mathrm{G}$ (1890-1904), which is not.

\section{Role of facilitation}

The significance of nutrient availability as a major control on colonization and succession on glacial forelands has long been a specific research focus. One of the earlier studies of a high-latitude successional setting examined nitrogen fixation resulting from lichen colonization of glacial drift in southern Iceland (Crittendon 1975). Subsequent studies on various glacial forelands on Svalbard focused largely on the contribution of cyanobacterial colonization during the pioneer stage in raising nutrient status prior to vascular plant colonization (Liengen and Olsen 1997; Liengen 1999; Hodkinson et al. 2003; Zielke et al. 2005). Previous investigations of the Skaftafellsj kull foreland found that the nitrogen content in the top $10 \mathrm{~cm}$ of soils ranged from $<0.1 \%$ at sites more proximal to the ice front to values mainly in the range of $0.1 \%$ to $0.2 \%$ (maximum $0.26 \%$ ) at the more distal sites (Tanner et al. 2013; Vilmundardóttir et al. 2015a). Therefore, advanced successional stages did not correlate greatly with soil nitrogen availability, similar to the findings of Robbins and Matthews (2014). Thus, facilitation by nutrient addition appears to be of very limited importance on the Skaftafellsj kull foreland.

The older portions of the foreland are an outwash plain with a subdued ridge and swale topography. The substrate of the ridges consists of coarse glacial outwash deposits that limit the available sites for deep-rooted vascular plants, while the swales contain a higher proportion of finer-grained sediments and host most of the birch trees. Vegetation coverage increased on older surfaces (> 100 years) primarily by the increase of bryophytes due to their lower requirements for nutrients and soil for rooting. Mori et al. (2017) concluded that although SR is strongly influenced by soil properties in early successional stages, the opposite relationship holds in later stages. However, we find no evidence for significant substrate modification at the older sites at Skaftafell, although we concede effective change could occur given much more time, e.g., the bryophytes can act as wind baffles, trapping silt-sized sediments. From our observations, we conclude that the spread of mosses effectively decreased the availability of sites for larger, rooted vascular plants, except in swales that capture the finer-grained sediments that host shrubs and trees. We note, however, that as described above the measurements made in 2014 indicate that the proportion of low shrubs is increasing on the oldest surfaces irrespective of topography.

Notably, to preserve the native community of the landscape, the personnel of the national park has actively prevented the incursion of Arctic Lupine (Lupinus nootkatensis), an aggressive invasive species that is common on the south coast of Iceland. Arctic Lupine is a legume and a prolific seed producer that was imported to 
Iceland in the early to mid-twentieth century to control soil erosion and reclaim eroded lands because it grows well in nutrient-poor soils and spreads rapidly (Magnússon 2010). The growth of lupine, extensive patches of which occur nearby on the Svinafellsj kull foreland, would promote fixed nitrogen availability in the soil and enhance the growth of vascular plant species, but because it grows quickly and in dense thickets, it displaces other species.

Finally, modern climate warming, which is driving accelerated glacial retreat, might logically be expected to promote more rapid successional changes (Starfield and Chapin 1996). Although the 7-year measurement interval of this study is insufficient to address this question, Hodkinson et al. (2003) concluded that rates of successional change appear to be limited more by nutrient availability. This is not to say that climate change will not affect the composition of the climax community, however. For example, Jägerbrand et al. (2012) found that bryophyte and shrub coverage correlated negatively under natural conditions, but this negative correlation disappeared under artificial warming conditions. Therefore, both autogenic and allogenic processes may play roles in the longer term in controlling both rates and directions of succession (Matthews and Whittaker 1987; Matthews 1992; Whittaker 1993).

\section{Conclusions}

Measurements of $\mathrm{VC}$ and species counts conducted in 2007 and repeated at the same GPS coordinates in 2014 record a trend of land surface cover increasing from the youngest sites to the oldest on the chronosequence of the Skaftafellsj kull foreland. Both SR and SD increased from the youngest sites through mid-successional stage sites (site E; ca. 1938), but SR, SD, and SE decreased on the oldest portions of the chronosequence, reflecting changes in community structure. Cover by low shrubs, graminoids, forbs, and willows all increased through mid-successional stages but decreased in late stages as mosses became more dominant. We attribute the dominance of bryophytes on older land surfaces to species competition for limited sites on a nutrient-limited landscape.

The results of the study indicate that reliance on GPS coordinates to return to previously measured sites is a useful technique, although imperfect, particularly on younger surfaces where meter-scale variation in vegetation cover is greater. During the 7-year interval between the measurements, $\mathrm{VC}$, cover by mosses and cover by low shrubs all increased at middle to late stages, although most of these changes were not statistically significant. Changes in community structure in 7 years at the late-stage sites, specifically, the increase in the proportion of low shrubs, suggests that succession has not yet achieved an equilibrium climax community after ca. 100 years. Thus, the oldest portion of the chronosequence may yet transition to a mixed moss-low shrub heath community, or ultimately, to a birch woodland.

\section{Abbreviations \\ SD: Species richness; SE: Species evenness; SR: Species richness; \\ VC: Vegetative cover}

\section{Acknowledgements}

Numerous individuals deserve mention for contributions to the collection of the data presented herein, including A. Bogolin, J. Curry, A. Curtin, L. Dishaw, M. Nivison, S. Peltz, K. Ryan, A. Walker, A. Wilkinson and the late and beloved Dr. David Smith. Permission to conduct the study was granted generously by O. Kristiansson and R. Hreinsdottir, directors of the Vatnajökull National Park in 2007 and 2014, respectively. This manuscript was greatly improved by the thoughtful comments of two anonymous reviewers.

\section{Funding}

The collection, analysis and write-up of the data herein were supported by Le Moyne College.

\section{Availability of data and materials}

The raw data used to support the findings of this study are available in xIsx format from the corresponding author upon request.

\section{Authors' contributions}

TG and LT jointly designed the project and supervised data collection. TG analyzed the data. LT was primarily responsible for the manuscript with input and editing by TG. All authors read and approved the final manuscript.

Ethics approval and consent to participate

Not applicable.

\section{Consent for publication}

Not applicable.

\section{Competing interests}

The authors declare that they have no competing interests.

\section{Publisher's Note}

Springer Nature remains neutral with regard to jurisdictional claims in published maps and institutional affiliations.

\section{Author details}

'Jacobs School of Medicine and Biomedical Sciences, State University of New York at Buffalo, Buffalo, NY 14203, USA. ²Department of Biological and Environmental Sciences, Le Moyne College, Syracuse, NY 13214, USA.

Received: 8 January 2019 Accepted: 13 March 2019

Published online: 17 April 2019

\section{References}

Albert JS, Reis RE (2011) Historical biogeography of neotropical freshwater fishes. University of California Press, Berkeley

Baldursson S, Guðnason J, Hannesdóttir H, Pórðarson P (2018) Nomination of Vatnajökull National Park for inclusion in the World Heritage List. Reykjavík, Vatnajökull National Park

Burga CA, Krüsi B, Egli M, Wernli M, Elsener S, Ziefle M, Fischer T, Mavris C (2010) Plant succession and soil development on the foreland of the Morteratsch glacier (Pontresina, Switzerland): straight forward or chaotic? Flora 205:561-576

Butters FK (1914) Some peculiar causes of plant distribution in the Selkirk Mountains, British Columbia. Minnesota Botan Stud 4:313-331

Chapin FS, Walker LR, Fastie CL, Sharman LC (1994) Mechanisms of primary succession following deglaciation at Glacier Bay, Alaska. Ecol Monogr 64:149-157

Coaz J (1887) Erste ansiedelung phanerog. Pflanzen auf von gletschern boden. Mitteilungen der Naturforschenden Gesellschaft in Bern: aus dem Jahre 1886, 1143-1168:3-12 
Connell JH, Slatyer RO (1977) Mechanisms of succession in natural communities and their role in community stability and organization. Amer Natural 111: 1119-1144

Cooper WS (1916) Plant succession in the Mount Robson region, British Columbia. Plant World 19:211-238

Cooper WS (1923) The recent ecological history of Glacier Bay, Alaska: III. Permanent quadrats at Glacier Bay: an initial report on a long-period study. Ecology 4:355-365

Cooper WS (1931) A third expedition to Glacier Bay, Alaska. Ecology 12:61-95

Cooper WS (1939) A fourth expedition to Glacier Bay, Alaska. Ecology 20:130-155

Crittendon PD (1975) Nitrogen fixation by lichens on glacial drift in Iceland. New Phytol 74:41-49

Crocker R, Major J (1955) Soil development in relation to vegetation and surface age at Glacier Bay, Alaska. J Ecol 45:427-448

Dowdeswell JA (1995) Glaciers in the high Arctic and recent environmental change. Phil Trans Royal Soc London Ser A 352:321-334

Eichel J (2019) Vegetation succession and biogeomorphic interactions in glacier forelands. In: Heckmann T, Morche D (eds) Geomorphology of proglacial systems. Geography of the Physical Environment. Springer, Cham

Elven R, Ryvarden L (1975) Dispersal and primary establishment of vegetation. In: Wielgolaski FE (ed) Fennoscandian tundra ecosystems, part 1: plants and microorganisms. Springer, Berlin, pp 82-85

Fægri K (1933) Über die längenvariationen einiger Gletscher des Jostedalsbre und die dadurch bedingten pflanzensukzessionen. Bergens Museum Årbok 1933. Naturvidenskapelig rekke 7:1-255

Fastie CL (1995) Causes and ecosystem consequences of multiple pathways of primary succession at Glacier Bay, Alaska. Ecology 76:1899-1916

Friedel H (1934) Boden- und vegetationsentwiklung um pasterzenufer. Carinthia 2:29-41

Friedel H (1937) Boden- und vegetationsentwiklung im vorfelde des Rhonegletschers. Vorläufiger bericht. Berichtüber das Geobotanische Forschungsinstitutt Rübel in Zurich, für 1937, pp 65-76

Friedel H (1938) Die pflanzenbesiedlung im vorfeld des Hintereisferners. Zeitschrift für Gletscherkunde 26:215-239

Geiger R (1971) The climate near the ground. Cambridge, Mass., Harvard University Press

Hannesdóttir H, Björnsson H, Pálsson F, Ađalgeirsdóttir G, Sv G (2014) Area, volume and mass changes of Southeast Vatnajökull ice cap, Iceland, from the little ice age maximum in the late 19th century to 2010. Cryosph Discuss 8: $1-55$

Hill MO (1973) Diversity and evenness: a unifying notation and its consequences. Ecology 54:427-432

Hodkinson ID, Coulson SJ, Webb NR (2003) Community assembly along proglacial chronosequences in the high Arctic: vegetation and soil development in north-West Svalbard. J Ecol 91:651-663

Hoinkes H (1954) Beitrígezurkennte des gletscherwindes. Archiv fur Meteorologie, Geophysik und Bioklimatologie Ser B 6:36-53

Huggett RJ (1998) Soil chronosequences, soil development, and soil evolution: a critical review. Catena 32:155-172

IPCC (2014) Climate Change 2014: Synthesis Report. Contribution of Working Groups I, II and III to the Fifth Assessment Report of the Intergovernmental Panel on Climate Change [Core Writing Team, Pachauri RK, Meyer LA (eds)]. IPCC, Geneva, Switzerland

Jägerbrand AK, Kudo G, Alatalo JM, Molau U (2012) Effects of neighboring vascular plants on the abundance of bryophytes in different vegetation types. Polar Sci 6:200-208

Jones CC, del Moral R (2005) Patterns of primary succession on the foreland of Coleman glacier, Washington, USA. Plant Ecol 180:105-116

Jones GA, Henry GHR (2003) Primary plant succession on recently deglaciated terrain in the Canadian high Arctic. J Biogeogr 30:277-296

Kjær U, Olsen SL, Klanderud K (2018) Shift from facilitative to neutral interactions by the cushion plant Silene acaulis along a primary succession gradient. J Veg Sci 29:42-51

Kristinsson H (2013) Flowering plants and ferns of Iceland, 2nd edn. Málog Menning, Reykjavik

Lefauconnier B, Hagen JO, Orbaeck JB, Melvold K, Isaksson E (1999) Glacier balance trends in the Kongsfjorden area, western Spitsbergen, Svalbard, in relation to the climate. Polar Res 18:307-313

Liengen T (1999) Environmental factors influencing the nitrogen fixation activity of free-living cyanobacteria from a high arctic area, Spitsbergen. Can J Microbiol 45:573-581
Liengen T, Olsen RA (1997) Seasonal and site-specific variations in nitrogen fixation in a high arctic area, Ny-Ålesund, Spitsbergen. Can J Microbiol 43:759-769

Liestøl O (1988) The glaciers in the Kongsfjorden area, Spitsbergen. Nor Geogr Tidsskr 42:231-238

Lindröth CH (1965) Skaftafell, Iceland: a living glacial refugium. Oikos Supplement 6:1-142

Lüdi W (1921) Die pflanzengesellschaften des lauterbrunnentalles und ihre sukzession. Beitrage zur Geobotanischen Landesaufnahme 9:1-364

Lüdi W (1958) Beobachtungenüber die Besiedlung von gletschervorfeldern in den Schweizeralpen. Flora 146:386-407

Magnússon B (2010) NOBANIS—Invasive Alien Species Fact Sheet_Lupinus nootkatensis, Online Database of the European Network on Invasive Alien Species-NOBANIS, http://www.nobanis.org/

Matthews JA (1978) Plant colonization patterns on a gletschervorfeld, southern Norway: a mesoscale geographical approach to vegetation change and phytometric dating. Boreas 7:155-178

Matthews JA (1992) The ecology of recently deglaciated terrain: a geoecological approach to glacier forelands and primary succession. Cambridge University Press, New York

Matthews JA, Whittaker RJ (1987) Vegetation succession on the Storbreen glacier foreland, Jotunheimen, Norway: a review. Arctic Alp Res 19:385-395

Mori AS, Osono T, Cornelissen JHC, Craine J, Uchida M (2017) Biodiversityecosystem function relationships change through primary succession. Oikos 126:1637-1649

Negri G (1934) La vegetazione delle morene del Ghiacciaio del Lys (Monte Rosa). Bolletino Comitato Glaciologico Italiano (Roma) 14:105-172

Negri G (1936) Osservazioni di U. Monterin su alcuni casi di invasione della morene gallegianti dei Ghiacciai del Monte Rosa da parte della vegetazione (contav. XVII e XVIII). Nuovo Giorniale Botanicoltaliano (Firenze) 42:699-712

Perrson $\AA$ (1964) The vegetation at the margin of the receding glacier Skaftafellsjökull, southeastern Iceland. Bot Notiser 117:323-354

Robbins JA, Matthews JA (2014) Use of ecological indicator values to investigate successional change in boreal to high-alpine glacier-foreland chronosequences, southern Norway. The Holocene 24:1453-1464

Sigurðsson O (2005) Glacier variations in Iceland 1930-1960, 1960-1990 og 20032004. Jökull 55:163-170

Starfield AM, Chapin FS III (1996) Model of transient changes in Arctic and boreal vegetation in response to climate and land use change. Ecol Appl 6:842-864

Tanner LH, Walker AE, Nivison M, Smith DL (2013) Changes in soil composition and floral coverage on a glacial foreland chronosequence, southern Iceland. Open J Soil Sci 3:191-198

van Leeuwen JP, Lair GJ, Gísladóttir G, Sandén T, Bloem J, Hemerik L, de Ruiter PC (2018) Soil food web assembly and vegetation development in a glacial chronosequence in Iceland. Pedobiologia 70:12-21

Vilmundardóttir OK, Gísladóttir G, Lal R (2014) Early stage development of selected soil properties along the proglacial moraines of Skaftafellsjökull glacier, SE-Iceland. Catena 121:142-150

Vilmundardóttir OK, Gísladóttir G, Lal R (2015a) Soil carbon accretion along an age chronosequence formed by the retreat of the Skaftafellsjökull glacier, SEIceland. Geomorphology 228:124-133

Vilmundardóttir OK, Gísladóttir G, Lal R (2015b) Between ice and ocean; soi development along an age chronosequence formed by the retreating Breiðamerkurjökull glacier, SE-Iceland. Geoderma 259-260:310-320

Vreeken WJ (1975) Principle kinds of chronosequences and their significance in soil history. J Soil Sci 26:378-394

Whittaker RJ (1993) Plant population patterns in a glacier foreland succession: pioneer herbs and later-colonizing shrubs. Ecography 16:117-136

Wójcik G (1973) The results of the meteorological investigations on the foreland of Skeiðarárjökull. Geogr Pol 26:157-183

Zielke M, Solheim B, Spjelkavik S, Olsen R (2005) Nitrogen fixation in the high Arctic: role of vegetation and environmental conditions. Arctic Antarctic Alp Res 37:372-378

Zollitsch B (1969) Die vegetationsentwicklung im Pasterzenvorfeld. Wissenschaftliche Alpenverieinsheft 21:267-290 